to the general welfare. The fellows of the pure chemistry department have completed a number of important investigations on quinine, the cinchona alkaloids, etc., while the Institute has also supported investigations on pneumonia and pulmonary diseases at the Western Pennsylvania Hospital.

\section{Aquarist and Pond Keeper}

The sixth volume of the Aquarist and Pond Keeper, which opens with the March-April issue, has a change of cover, a new headpiece and other improvements in printing and illustrations. The magazine keeps up its character in every way, and is full of information for those who are fond of aquaria, vivaria and pond culture. The articles in the present number include the first of a new series by Arthur Denham on the keeping, breeding and rearing of tropical fishes, and aquarium notes by E. G. Boulenger, director of the Zoological Society's aquarium, and by S. W. Weller, curator of the Brighton Aquarium. An angler fish or 'fishing frog' more than three feet in length, said to be the finest specimen of its kind ever exhibited alive, has been acquired for the Brighton Aquarium. It will be interesting to see how long it lives, for this species is notoriously difficult to keep in confinement, especially those of such a large size.

\section{The Merseyside Aquarium Society}

ONE of the most extensive collections of British fresh-water aquaria and aquatic and river-side vegetation, in addition to foreign aquaria, has lately been brought together by the Merseyside Aquarium Society at its aquarium at Cliff House, Wallasey, which was opened by the Mayor of Wallasey in March 1932. The collection, which now comprises some sixty tanks, is claimed to be the most extensive of its kind in the North of England, and situated in extensive glass-houses, is largely the result of much hard work by enthusiasts in all classes of life in an effort to establish a really efficient scientific and public aquarium on Merseyside. The Merseyside Aquarium Society was instituted in 1926, largely through the efforts of Mr. F. Jefferies, a past president of the Liverpool Naturalists' Field Club, and incorporated in 1930, and its first president was the late Prof. James Johnstone. The president of the Society is Alderman A. H. Evans of Wallasey, the vicepresidents Prof. J. H. Orton, professor of zoology in the University of Liverpool, W. S. Laverock, lately of the Liverpool Museums, and Alderman D. R. Charlesworth, ex-mayor of Wallasey, and the honorary secretary, Mr. F. Jefferies. By a system of exchange, the Cliff Aquarium has acquired a number of valuable exhibits from the New York Aquarium Society, and it has lately been successful in breeding and rearing the axolotl (Amblystoma) to maturity. The present premises have been loaned the Society by the Wallasey Corporation, but the Aquarium is only considered a nucleus for a much larger building which it is hoped to have built as a municipal affair in the future. The Society issues a volume of Proceedings, holds six indoor meetings annually, and affords special help for the amateur aquarists, for the exchange of knowledge and experience amongst experts, and to promote school aquaria and vivaria.

\section{Advances in Oceanographical Research}

THE great and growing importance of fundamenta research in marine biology and oceanography has recently been emphasised by the launch of two new vessels specially ordered and designed for this work. On September 23, 1933, a new French research vessel, the Président-Théodore-Tissier, left the builder's yard. This ship, built to the order of L'Office Scientifique et Technique des Pêches Maritimes de France, is approximately $160 \mathrm{ft}$. in length, fitted with up-to-date Diesel engines capable of producing a maximum speed of 11 knots, and fully equipped with all the latest apparatus for both oceanographical and biological researches. The Président-ThéodoreTissier has now completed her trials and is already in commission. A few months before the launch of the French vessel, the Danish Biological Station, Copenhagen, took over from the builders the new research ship Biologen (Report of the Danish Biological Station to the Ministry of Shipping and Fisheries, 38, 1933. Copenhagen: C. A. Reitzel). Though considerably smaller than the PrésidentTheodore-Tissier, the Danish vessel is also fully equipped for carrying out scientific work in both narrow and high seas. In view of the acquisition of these two highly efficient modern research vessels by foreign powers, it is all the more regrettable that H.M.S. Challenger, originally destined for similar work by Great Britain, should have had to be given over to other purposes, and the activities of our existing ships seriously curtailed.

\section{A Potato Research Station}

THE establishment of such a station in one of the important potato-growing districts is advocated by Sir John Russell in the foreword to the report of the sixteenth Rothamsted Conference, upon "Problems of Potato Growing" (Harpenden : Rothamsted Experimental Station. 2s.). Sir John concludes that economical production of potatoes necessitates the use of good seed of the most suitable varieties, appropriate schemes of manuring and cultivation, control of insect and fungus pests and of other agencies causing disease, and methods for dealing with excess produce. All these topics are dealt with by expert contributors in this report. The fields of research developed around this homely plant, notably the virus disease problems, show how technical and specialised are the problems raised by this crop, and though the present research and advisory system deals very effectively with them to a point, Sir John concludes that there is room for such a special research station continuously concerned with investigations into the physiology of the potato and the utilisation of the tuber.

\section{Research Regulations in Germany}

THe April number of the Fight Against Disease, the quarterly journal of the Research Defence Society, 
among other matter, gives extracts from the new German law controlling vivisection, which show that the German regulations governing experiments on living animals are substantially the same as those which have been enforced by the Home Secretary in Great Britain for more than half a century.

\section{National Baby Week Council}

The annual report of this Council, recently issued, describes the work accomplished during 1933 and constitutes another record of increased activity and influence. A tribute is paid to the co-operation of the Press and of shops and stores in propaganda respect. ing maternity and child welfare problems. It is suggested that propaganda should this year be devoted to the subject of "The Making of an A.1. Nation", and "National Baby Week" is to be celebrated on July 1-7. The Council has suffered from the financial stringency, but by exercising the strictest economy, income for the year exceeded expenditure by the small margin of about $£ 12$.

\section{South-Eastern Union of Scientific Societies}

The thirty-ninth Annual Congress of the SouthEastern Union of Scientific Societies will be held at the University of Reading on July 11-14, under the presidency of Prof. H. L. Hawkins, professor of geology in the University. On July 11, Prof. Hawkins will deliver his presidential address entitled "Fossils and Men". The presidents of sections will deliver the following addresses during the Congress: T. D. Kendrick (Archæology), "The Art and Archæology of the Early Anglo-Saxons"; Dr. Macgregor Skene (Botany), "Some Problems of Germination"; Dr. C. B. Williams (Zoology), "Insect Immigration in Great Britain"; T. H. Edmunds (Geology), "The Water Supply and Geology of the South-East of England; C. H. Grinling (Regional Survey), "Surrey for Action". On July 13, at 8 p.m., Prof. E. B. Poulton will deliver a public lecture entitled "The Power of Changing Colour as a Form of Protective Resemblance". Further information can be obtained from the Hon. General Secretary, 14, High View Close, Norwood, S.E.19.

\section{American Academy of Arts and Sciences}

At the annual meeting of the American Academy of Arts and Sciences held on May 9, the following officers were elected for 1934-35 : President, Prof. G. H. Parker ; Corresponding Secretary, Prof. Tenney L. Davis; Recording Secretary, W. E. Clark; Treasurer, I. Bowditch ; Librarian, Prof. Alfred C. Lane; Editor, Prof. Robert P. Bigelow; Foreign Honorary Members, Prof. R. A. Fisher, Galton professor of eugenics in University College, London ; Prof. A. V. Hill, Foulerton Research professor of the Royal Society, and University professor of physiology in University College, London; Prof. Arthur H. Holmes, professor of geology in the University of Durham; Prof. Paul Janet, professor of electrotechnics in the Sorbonne, Paris; Prof. Luigi Lombardi, Rome; and Prof. R. Willstätter, Munich.

\section{Announcements}

Prof. A. V. HIIL will open a discussion at the Royal Society on June 14 on "Methods of Measuring and Factors Determining the Speed of Chemical Reaction".

The Right Hon. Walter E. Elliot, Minister of Agriculture and Fisheries, will inspect the field plots and laboratories of the Rothamsted Experimental Station on June 20, at 11.15 a.m. On the same day, Mr. Elliot will present to the Trustees the deeds of the land newly acquired as a result of the recent public appeal.

Prof. J. B. Conant, president of Harvard University, formerly professor of chemistry in the University, has been awarded the medal of the American Institute of Chemists. The award is made in recognition of "outstanding service to the science of chemistry and the profession of chemists in America". Prof. Conant is well known for his work on reduction and oxidation in organic chemistry, and on hæmoglobin and chlorophyll.

WE have received the second supplement, 19311933, to the "Catalogue of Lewis's Medical and Scientific Lending Library" (London: Lewis's Library, 136, Gower Street, London, W.C.1. 2s. net). Works are listed alphabetically under authors' names, and at the end there is a classified index of subjects, under each of which authors' names are given, and the full title of the works will be found on reference to the body of the catalogue. All the sciences appear to be represented, and the list contains nearly 3,000 titles.

Applications are invited for the following appointments, on or before the dates mentioned :-An assistant lecturer in physics in King's College, London - The Secretary (June 12). A veterinary officer to the Berkshire County Council-The Clerk, Shire Hall, Reading (June 19). Assistant lecturers in geology and geography, chemistry, and physics at University College, Swansea-The Registrar (June 20). A superintendent of parks in the Borough of BarkingThe Town Clerk, Town Hall, Barking (June 20). A lecturer (woman) in geography at Norwich Training College-The Principal (June 20). An inspector of agriculture in the Department of Agriculture and Forests, Sudan Government-The Controller, Sudan Government London Office, Wellington House, Buckingham Gate, London, S.W.1 (June 21). A lecturer in pure and, applied technology at Leicester College of Technology-The Director of Education (June 22). An assistant in the Department of Natural Philosophy in the University of St. Andrews-The Secretary (June 23). A senior lecturer in mathematics at the Huguenot University College, Wellington, Cape Province, South Africa-The Registrar (Aug. 14). Evening teachers of pure and applied mathematics, economics, economic geography, etc., at the Wandsworth Technical Institute, London, S.W.18-The Secretary.

Erratum : Nature, June 2, p. 837. "Chemistry of Red and Brown Algæ." For "polymerised uronic acid" read "polymerised mannuronic acid". 